\title{
PERAN GLUKOSAMIN PADA OSTEOARTRITIS
}

\author{
Pratiwi Utami \\ Sonny J. R. Kalangi \\ Taufiq F. Pasiak
}

\begin{abstract}
Bagian Anatomi-Histologi Fakultas Kedokteran Universitas Sam Ratulangi Manado
Email: Thy_why_imoet19@yahoo.com
\end{abstract}

\begin{abstract}
Osteoarthritis is a degenerative disease and manifests itself as the most common type of arthritis affecting older people. This disease can cause significant pain and functional disability in the affected individuals. The therapy for osteoarthritis is easily available but the results are without certainty. Symptomatically therapeutic agents such as acetaminophen and NSAIDs are only beneficial for relieving the symptoms. Unfortunately, these agents can trigger severe side effects in some patients or may be contraindicated. Glucosamine has been evaluated in several studies as an agent to relieve pain, increase functional activity, and slow the progression of osteoarthritis, especially in the knees. Studies have reported some improvement in pain and disability in osteoarthritic patients related to the use of glucosamine. Based on the current evidence, a combination of glucosamine sulfate and chondroitin sulfate shows the greatest potential as a therapeutic intervention for patients who might risk side effects from other oral medications currently in vogue. However, research is still needed to explore the benefits of glucosamine or its combination forms in order to ensure safety for long-term use.
\end{abstract}

Keywords: osteoarthritis, glucosamine, pain.

\begin{abstract}
Abstrak: Osteoartritis merupakan penyakit degeneratif yang menyebabkan rasa nyeri dan cacat fungsional pada individu yang terkena dan umumnya mempengaruhi lanjut usia. Kemajuan dalam pengobatan osteoartritis relatif tersedia tetapi belum secara pasti untuk mengobatinya. Terapi andalan seperti asetaminofen dan obat NSAID hanya untuk mengobati gejala, tetapi dapat memicu efek samping yang parah pada pasien atau mungkin merupakan kontraindikasi. Beberapa studi mengemukakan glukosamin sebagai agen untuk menghilangkan rasa nyeri, meningkatkan aktivitas fungsional, dan memperlambat progresivitas osteoarthritis, terutama pada lutut. Juga telah dilaporkan perbaikan dalam rasa nyeri dan kecacatan yang terkait dengan penggunaan glukosamin baik sebagai agen tunggal maupun bentuk kombinasi glukosamin sulfat dengan kondroitin sulfat. Penggunaan produk kombinasi tersebut tampaknya memiliki potensi besar untuk pasien yang berisiko akibat efek samping terapi oral. Masih dibutuhkan penelitian lanjut mengenai manfaat dan kemanan glukosamin terutama pada pemakaian jangka panjang.
\end{abstract}

Kata kunci: osteoartritis, glukosamin, nyeri.

Ilmu kedokteran selalu berusaha memperpanjang dan memperbaiki kualitas kehidupan manusia baik dalam segi pencegahan ataupun pengobatan. Pengobatan yang cepat dan tepat diarahkan sebagai tujuan khusus memerangi berbagai macam jenis penyakit dalam masyarakat. ${ }^{1,2}$

Segala upaya dilakukan untuk mene- mukan berbagai macam penyakit dan pengobatannya. Berbagai penelitian dilakukan dan dikembangkan. Sebagaimana contoh, Bagaimana manusia bisa dapat mencegah, memperbaiki 'meremajakan' kembali selsel yang sudah tua sehingga dapat lebih awet dan lama untuk dapat mendukung kehidupan. ${ }^{1}$ 
Penyakit sendi yang merupakan salah satu sampel penyakit degeneratif adalah osteoartritis. Kondisi di mana sendi terasa nyeri akibat inflamasi ringan yang timbul karena gesekkan ujung tulang penyusun sendi. Hilangnya fungsi sendi menyebabkan gangguan aktifitas dan mengurangi kualitas hidup. ${ }^{3,4}$

World Health Organization melaporkan 40 persen penduduk dunia lansia akan menderita osteoartritis lutut, dari jumlah tersebut, 80 persen mengalami keterbatasan gerak sendi. ${ }^{4}$

Glukosamin merupakan indikator yang direkomendasikan sebagai alternatif penyembuh. Namun pada beberapa pelitian ditemukan fakta bahwa glukosamin bukan merupakan penyembuh melainkan hanya suplemen yang memberikan efek kecil pada proses perbaikan sendi. ${ }^{5}$

\section{GLUKOSAMIN}

Glukosamin merupakan gula amino dan prekursor penting dalam sintesis biokimia protein, glikosilasi dan lipid. Dalam industri, glukosamin diproduksi secara komersial oleh hidrolisis eksoskeleton krustasea atau melalui fermentasi dari biji-bijian seperti jagung atau gandum. ${ }^{5}$

Glukosamin pertama kali ditemukan pada tahun 1876 oleh Georg Ledderhose melalui hidrolisis kitin dengan asam klorida pekat. Stereokimia ini tidak sepenuhnya didefinisikan sebelum disempurnakan oleh Walter Haworth 1939. D-Glukosamin dibuat secara alami dalam bentuk glukosamin-6-fosfat, dan merupakan prekursor biokimia dari semua yang mengandung nitrogen gula secara khusus, glukosamin-6-fosfat disintesis dari fruktosa 6-fosfat dan glutamin oleh deaminase glukosamin-6-fosfat sebagai langkah pertama dari jalur biosintesis hexosamine. Pada produk akhir dari jalur ini dihasilkan uridin difosfat $\mathrm{N}$-asetilgluko-samin (UDPGlcNAc), yang kemudian digunakan untuk membuat glikosaminoglikan, proteoglikan, dan glikolipid. ${ }^{6,7}$

Gambar 1 menjelaskan skema dari jalur biosintesis heksosamin. Glukosamin diproduksi dalam tubuh melalui jalur biosintesis heksosamin. Dalam jalur ini, glukosa memasuki sel melalui transporter glukosa dan fruktosa di metabolisme untuk fruktosa-6-fosfat oleh suatu heksokinase. ${ }^{8}$

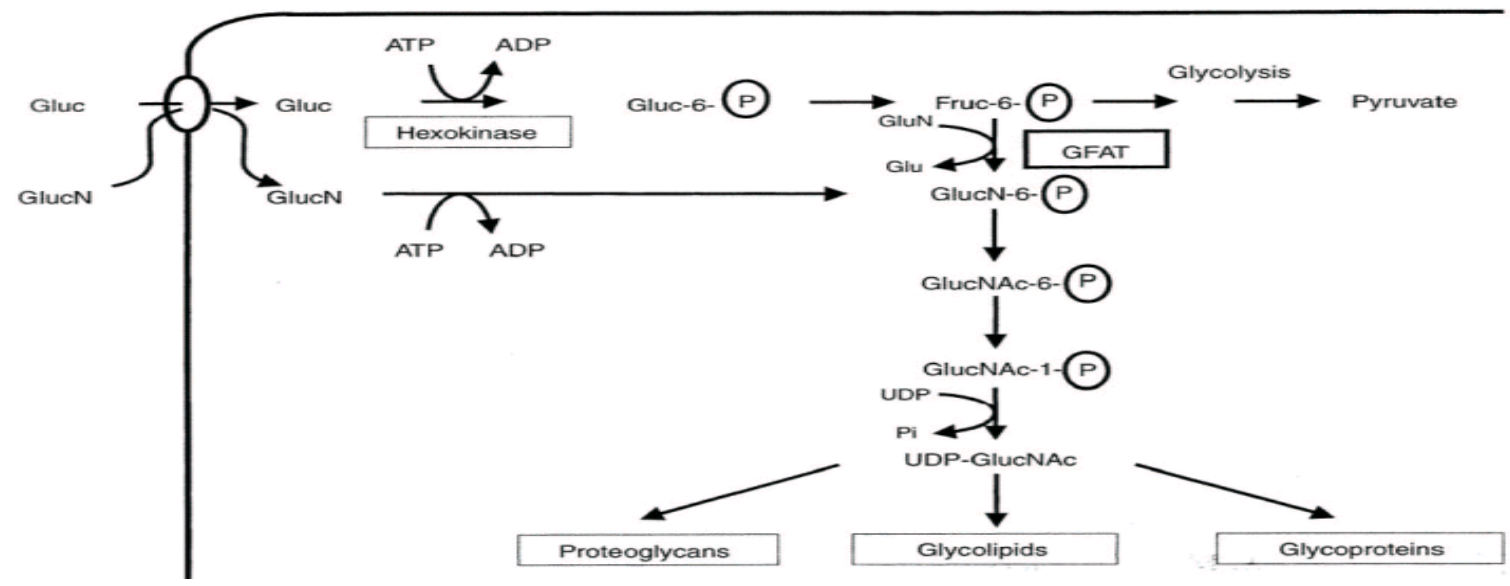

Gambar 1. Jalur biosintesis heksosamin. Pusat peran asetilglukosamin-6-fosfat (GlucN-6-P) dalam metabolisme gula amino dan sintesis proteoglikan, glikolipid, dan glikoprotein. Singkatan: Gluc= Glukosa; Gluc-6-P= Glukosa-6-fosfat; Fruc-6-P= Fruktosa-6-fosfat; GlucN= Glukosamin; GlucNAc-6-P = asetilglukosamin-6-fosfat; GlucNAc-1-P= asetilglukosamin-1-fosfat; UDP= uridin; GluN= Glutamine; GFAT= Glutamin: fruktosa-6-fosfat-amidotransferase. ${ }^{8}$ 
Fruktosa-6-fosfat bentuk glukosamin-6fosfat dalam reaksi dikatalisis oleh glutamin yang membatasi enzim: fruktosa6-fosfat-amidotransferase (GFAT) di mana glutamin berfungsi sebagai donor gugus amino (Schleicher \& Weigert, 2000). ${ }^{6,8,9}$

Berdasarkan fungsionalnya persendian. Glukosamin adalah zat yang secara alami memperbaiki tulang rawan. Mekanisme kerja glukosamin menghambat sintetis glikosaminoglikan dan mencegah destruksi tulang rawan. Glukosamin merangsang selsel tulang rawan untuk pembentukan proteoglikan dan kolagen yang merupakan protein esensial untuk memperbaiki fungsi persendian. $^{10}$

Gambar 2 memperlihatkan struktur atau rangkai kimia glukosamin yang berikatan membentuk rumus molekul “C6H13NO5”, yaitu: ${ }^{6}$

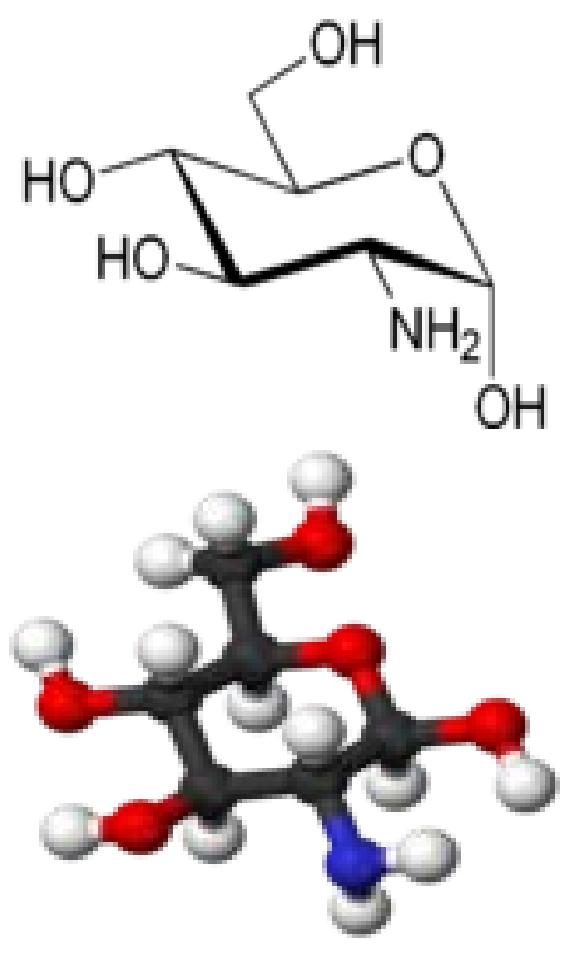

Gambar 2. Struktur glukosamin.

Dalam studi penelitan Kelompok Kerja Seleksi Kimia, glukosamin digunakan secara luas untuk memaksimalkan efek potensial. Namun demikian, tidak ada studi toksisitas kronis yang mendukung keamanan seperti penggunaan jangka panjang. ${ }^{6}$
Studi praklinis menunjukkan bahwa senyawa ini untuk tulang rawan dan tulang, berfungsi sebagai substrat dan stimulan biosintesis proteoglikan. Proteoglikan merupakan komponen penting dari kartilago artikular. Eksogen administrasi glukosamin dilaporkan dapat menghambat degradasi dan membangun kembali jaringan tulang rawan yang rusak. Glukosamin meningkatkan sintesis proteoglikan sehingga menghambat kerusakan tulang rawan yang disebabkan oleh osteoarthritis dan membantu menjaga keseimbangan antara proses katabolik dan anabolik tulang rawan. ${ }^{11}$

\section{OSTEOARTRITIS}

Osteoartritis adalah penyakit yang melemahkan sendi diarthrodial progresif yang berhubungan dengan penuaan. Pada tingkat molekuler, osteoartritis ditandai oleh ketidakseimbangan antara anabolik yaitu biosintesis matriks ekstraseluler dan katabolik yaitu degradasi jalur matriks ekstraseluler di mana kartilago artikular adalah situs utama dari cedera jaringan. Karakteristiknya menipisnya rawan sendi secara progresif disertai pembentukan tulang baru pada trabekula subkondral dan osteofit pada rawan sendi. ${ }^{12,13}$

Pada faktor pertumbuhan insulin-like growth factor-1, protein mengikat dan mengubah faktor-pertumbuhan beta berkontribusi untuk jalur anabolik termasuk kompensasi biosintesis protein matriks ekstraseluler. Jalur katabolik yang diubah oleh gen sitokin seperti IL-1 dan TNF-alpha diregulasi pada osteoartritis. Selain itu, IL1 dan TNF-alpha downregulate matriks protein ekstraseluler biosintesis sementara bersamaan upregulating MMP ekspresi gen. Ketika MMPs diaktifkan, degradasi matriks ekstraseluler tulang rawan menyebabkan tingkat MMP inhibitor endogen tulang rawan tidak dapat mengatur aktivitas MMP. Strategi terapi dirancang untuk memodulasi ketidakseimbangan antara jalur anabolik dan katabolik pada osteoartritis dapat mencakup aktivitas sitokin menetralisir atau ekspresi gen MMP atau jalur sinyal menghambat yang mengakibatkan 
apoptosis bergantung pada aktivitas caspase matang atau mitogen-diaktifkan protein kinase (MAPK) aktivitas. Aktivitas MAPK muncul penting untuk mengatur apoptosis kondrosit dan synoviocyte dan gen MMP. ${ }^{14}$

Peran patofisiologi kartilago artikular dimainkan sel ekstra seluler matriks interaksi, yang dimediasi oleh integrin permukaan sel. Dalam pengaturan fisiologis, integrin memodulasi sel / ECM sinyal, penting untuk mengatur pertumbuhan dan diferensiasi dan mempertahankan homeostasis tulang rawan. Selama osteoatritis, ekspresi integrin yang abnormal mengubah sel/ ECM dan memodifikasi sinyal sintesis kondrosit, dengan ketidakseimbangan pada destruktif sitokin selama faktor regulasi. IL-1, TNF-alpha dan pro-katabolik mengaktifkan degradasi sitokin enzimatik pada matriks tulang rawan dan tidak diimbangi dengan sintesis yang memadai inhibitor. ${ }^{11,14}$

Enzim utama yang terlibat dalam kerusakan ECM metalloproteinase (MMP), yang secara berurutan diaktifkan. Aktivitas MMP sebagian dihambat oleh inhibitor jaringan MMPs (TIMPs), yang sintesis rendah dibandingkan dengan produksi MMP pada osteoartritis tulang rawan. ${ }^{10}$

Menarik adalah peran faktor pertumbuhan seperti TGF-beta, IFG, BMP, NGF, dan lain-lain, yang tidak hanya memperbaiki kerusakan jaringan yang disebabkan oleh faktor-faktor katabolik, tapi memainkan peran penting dalam patogenesis osteoartritis. $^{13}$

\section{RAWAN SENDI PADA OSTEO- ARTRITIS}

Pada osteoartritis hilangnya rawan sendi merupakan titik sentral, rawan sendi secara bertahap akan mengalami degradasi dengan penurunan progresif jumlah proteoglikan. Oleh karena sintesis proteoglikan kolagen dan hialuronan meningkat pada osteoartritis, berarti aktivitas kataboliknya sangat tinggi. Walaupun mungkin penggunaan sendi berlebih merupakan factor terjadinya kehilangan rawan sendi tetapi peranan lisozom protease (Cathepsin) dan metalloprotease seperti stromelisin, kolagenase dan gelatinase cukup besar. Banyak peneliti berpendapat bahwa interleukin-1 sangat berperan pada progresivitas kerusakan rawan sendi. Sitokin ini diproduksi oleh sel mononuklear termasuk sel sinovia. IL-1 akan menstimulasi sintesis dan sekresi dan stromelisin, kolagenase, gelatinase dan tissue plasminogen aktivator. Diduga jumlah reseptor II-1 pada kondrosit sangat meningkat,sehingga meningkatkan sensitivitas terhadap IL-1. Growth factor berperan pada proses perbaikan, faktor pertumbuhan ini akan memodulasi metabolism kondrosit baik pada faktor katabolik rnaupun pada faktor anabolik. Growth factor tidak hanya meningkatkan sintesa proteoglikan, tetapi juga mengurangi reseptor II-1 pada kondrosit dan menurunkan degradasi proteoglikan. Kualitas rawan sendi yang diperbaiki umumnya tidak sebagus rawan sendi normal dalam menghadapi tekanan mekanik dan akhirnya sintesis proteoglikan akan merosot, kondrosit tidak mampu lagi memelihara rawan sendi dan terjadilah stadium akhir dari osteoarthritis yang disertai dengan hilangnya seluruh rawan sendi. ${ }^{14,15}$

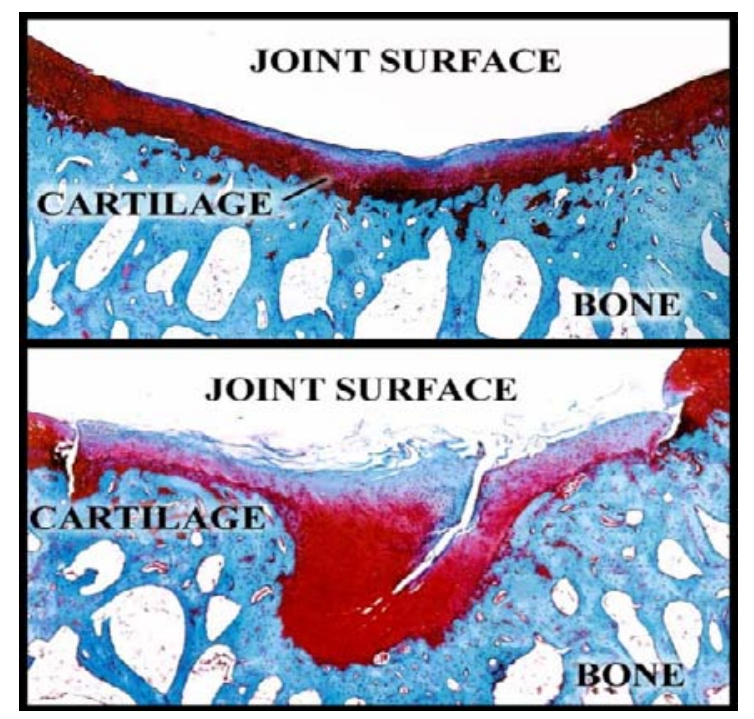

Gambar 3. Perbandingan antara kartilago normal (atas) dan kartilago athritis (bawah). (Dr. Nelson's osteoarthritis page. ${ }^{\text {dikutip dari } 12}$

Pada Gambar 3 terlihat gambaran permukan sendi dengan bentuk kartilago 
tebal dan sehat pada kartilago normal (atas); dan gambaran permukaan sendi dengan bentuk kartilago yang menipis pada kartilago artritis (bawah). ${ }^{16}$

\section{PERAN GLUKOSAMIN PADA OSTEOARTRITIS}

Glukosamin merupakan senyawa alami yang terdapat dalam tubuh, terutama pada jaringan penghubung dan jaringan tulang rawan. Glukosamin terbukti dapat men-stimulasi produksi tulang rawan dan meng-hambat enzim yang menghancurkan tulang rawan. ${ }^{10}$

Osteoartritis adalah hasil dalam katabolisme proteoglikan progresif dari tulang rawan karena ketidakseimbangan antara sintesis dan degradasi. Pada penurunan relatif dalam tulang rawan, proteoglikan mengubah afinitas dari matriks tulang rawan untuk mempermuda kemampuan $\mathrm{H} 2 \mathrm{O}$ untuk mengalir ke dalam atau di luar permukaan sendi. Telah ditunjukkan perubahan struktural dalam komposisi molekulmolekul ini memiliki dampak negatif pada sifat biomekanis artikular tulang rawan dewasa normal dan cairan sinovial. Perubahan dalam struktur molekul membuat artikular rentan terhadap efek dari kekuatan tekan, tarik dan geser yang terjadi selama gerak sendi kartilago normal. ${ }^{11,14}$

Secara teoritis, administrasi eksogen dari glikosaminoglikan, misalnya glukosamin sulfat untuk kondrosit akan memperbaiki ketidakseimbangan antara sintesis dan degradasi tulang rawan. Hal ini secara teoritis mencegah kerusakan lebih lanjut pada tulang rawan artikular sendi osteoartritis. Glukosamin mengambil bagian dalam sintesis glikosaminoglikan dan proteoglikan oleh kondrosit. Glukosamin berfungsi sebagai substrat untuk biosintesis kondroitin sulfat, asam hialuronat dan makromolekul lain yang terletak dalam matriks tulang rawan. ${ }^{6,10}$

\section{SIMPULAN}

Beberapa hasil penelitian menunjukkan bahwa glukosamin mempunyai efek positif dalam meringankan rasa nyeri dan memperbaiki sendi tulang penderita osteoartritis. Walaupun tidak secara signifikan, namun keputusan untuk menggunakan glukosamin sebagai terapi simptomatik utama ataupun glukosamin beserta kombinasinya pelan-pelan sudah mulai membuahkan hasil.

\section{DAFTAR PUSTAKA}

1. Tapan E. Telah terbit Majalah Cermin Dunia Kedokteran (CDK) edisi khusus mengenai STEM CELL [discussion list on the Internet]. 2006 Oct 6 [cited 2009 May 26]. Available from: http://tech.dir.groups.yahoo.com/group/ stemcell_indonesia/message/488.

2. Misnadiarly. Osteoatritis Penyakit Sendi pada Orang Dewasa dan Anak. Jakarta: Pustaka Popular Obor, 2010; p.11-3.

3. Briliantono S. Osteoatritis. Jakarta: Halimun Medical Center, 2011; p.7-8.

4. Partono M. Osteoartritis [homepage on the Internet]. Nodate [cited 2009 May 26]. Available from: www.http:// mukipartono.com/.

5. Yuliarti N. A to Z Food Supplement. Andi Offset, 2009; Suppl 1: 2.

6. Pantjita H. Metabolisme karbohidrat. In: Henra U, editor. Ikhtisiar Biokimia Dasar B. Jakarta: Balai Penerbit Fakultas Kedokteran UI, 2006; p.41-2.

7. McColl G. Glukosamin untuk asteoatritis lutut. Aust prescr. 2004;27:61-3.

8. Robert M, Daryl G, Victor R. Glikoprotein. Dalam: Anna P, Bani, Tiara S, editors. Biokimia Harper (Edisi Keduapuluh Lima). Jakarta: ECG, 2003; h.644-662.

9. Robbert M, Frederick K. Matriks ekstrasel. In: P Anna, Bani, S Tiara, editors. Biokimia Harper (Edisi Keduapuluh Lima). Jakarta: ECG, 2003; p.662-669.

10. Isbagio H. Struktur dan biokimia tulang rawan sendi. In: Sudoyo AW, Setiyohadi B, Alwi I, Simadibrata M, Setiati S, editors. Buku Ajar Ilmu Penyakit Dalam (Edisi Kelima). Jakarta: Interna Publishing, 2009; p.2382-4.

11. Isbagio H. Struktur rawan sendi dan perubahannya pada osteoatritis. Cermin Dunia Kedokteran. 2000;129:6.

12. Gartner PL, Hiatt JL, Strum JM. Tulang 
S34 Jurnal Biomedik, Volume 4, Nomor 3, Suplemen, November 2012, hlm. S29-34

rawan dan tulang. In: Saputra L, editor. Essential Biologi dan Histologi. Jakarta: Binarupa Aksara, 2011; p.12746.

13. Ceasario M. Osteoarthritis lutut [homepage on the Internet]. 2009 [cited 2011 Jul 18]. Available from: http:// www.medicalera.com/info.

14. Isbagio H. Struktur dan biokimia tulang rawan sendi. In: Sudoyo AW, Setiyohadi B, Alwi I, Simadibrata M, Setiati S, editors. Buku Ajar Ilmu Penyakit Dalam Jilid II (Edisi
Keempat). Jakarta: Pusat Penerbitan Departemen Ilmu Penyakit Dalam FK UI, 2006; p.1093-262.

15. Dr. Nelson's osteoarthritis page [homepage on the Internet]. 2009 [updated 2009 Sep 16; cited 2011 Jul 18]. Available from: http://www. allaboutarhritis.com.

16. Hilmy CR. Kelainan degeneratif dari sendi dari jaringan yang berhubungan. In: Soelarto L, editor. Kumpulan Kuliah Ilmu Bedah. Jakarta: Binarupa Aksara, 2010; p.536-9. 